Abstract AB0986 - Table

\begin{tabular}{|c|c|c|c|c|c|c|c|c|c|}
\hline Patient & Sex & Diagnostic age & Onset age & Arthritis & Location & Other musculoskeletal manifestations & Extra-articular manifestations & MEFV Mutation & Homo/ Heterocytosis \\
\hline 1 & $\mathrm{M}$ & 47 & 40 & Yes & Knee & No & No & p Glu148Gln & Heterocytosis \\
\hline 2 & $\mathrm{M}$ & 14 & 13 & Yes & Knee & No & No & R202Q & Homocytosis \\
\hline 3 & M & 22 & 22 & No & & No & Lymphocytic myocarditis & p Glu148GIn & Heterocytosis \\
\hline 4 & M & 52 & 47 & No & & Arthralgias & Abdominal pain. Pleuritis & R202Q & Heterocytosis \\
\hline 5 & M & 39 & 20 & Yes & PIPs & Arthralgias & Abdominal pain & $\mathrm{R} 202 \mathrm{Q}$ & Heterocytosis \\
\hline 6 & $\mathrm{M}$ & 61 & 54 & No & & Tendinopathy & Recurrent pericarditis & $\mathrm{R} 202 \mathrm{Q}$ & Homocytosis \\
\hline 7 & $\mathrm{M}$ & 17 & 16 & No & & No & Abdominal pain & $\mathrm{R} 202 \mathrm{Q}$ & Heterocytosis \\
\hline
\end{tabular}

Results: Seven patients with MEFV gene mutations were reviewed, all of them were women, ranging in age from 14 to 61 years old. Two of them had recurrent knee monoarthritis, one had a history of arthritis in the hands and erratic arthralgias, one had erratic arthralgias and two had no musculoskeletal manifestations. The 2 patients with intermittent hydrartrosis responded satisfactorily to colchicine, but not the other patients with other musculoskeletal manifestations.

Conclusions: Genetic testing of the common mutations of the MEFV gene should be considered in patients with recurrent episodes of monoarthritis without justifying cause (palindromic rheumatism, intermittent hydrartrosis, etc.)

Disclosure of Interest: None declared

DOI: 10.1136/annrheumdis-2017-eular.3429

\section{AB0987 THE RELATIONSHIP BETWEEN ANTI-INTERLEUKIN-1 THERAPIES AND MEFV GENE MUTATIONS IN FAMILIAL MEDITERRANEAN FEVER PATIENTS: A SINGLE CENTER EXPERIENCE}

M.E. Derin ${ }^{1}$, S. Gültekin ${ }^{2}$, M. Sahin ${ }^{3}$, A. Sahin ${ }^{1} .{ }^{1}$ Rheumatology - Internal Medicine; ${ }^{2}$ Internal Medicine; ${ }^{3}$ Biochemistry, Cumhuriyet University Medical Faculty, Sivas, Turkey

Background: Familial Mediterranean fever (FMF) is an autoinflammatory disease characterizing recurrent self-limiting attacks of inflammation mainly placed in serosal surfaces of the body with fever (1). Colchicine is an important weapon of the humanity in FMF treatment yet. However, the puzzle of inflammation was solved, and so, inflammasome complex and interleukin-1 were discovered. Eventually, new era started with anti-interleukin-1 agents in colchicine resistant and/or intolerant FMF patients (2).

Objectives: The aim of this study is to evaluate the effectiveness of antiinterleukin-1 (anti-IL-1) agents on the characteristics of attacks, the adverse effects associated with anti-IL-1 treatment, and relation between therapy and MEFV gene mutations in 23 FMF patients with resistant and/or intolerant to colchicine.

Methods: Between January 2015 and December 2016, twenty-three-FMF patients that following-up at Cumhuriyet University Medical Faculty Rheumatology-Internal Medicine Department were included in to the study. Anakinra $(69,6 \%)$, and canacinumab $(30,4 \%)]$ were used in 23 FMF patients. 20 cases were resistant to colchicine, 3 were intolerant to colchicine.

Results: The median age of the patients was 28 years,(18-54) and the median age at diagnosis was 20 years $(3-50)$. Of the FMF patients, nine $(39.1 \%)$ were female and fourteen $(60.9 \%)$ were male. The distribution of MEFV gene mutation frequencies in the FMF patients was no mutation in one $(4,3 . \%)$ patient, M694V heterozygous in nine (39,1\%), M694V homozygous in $7(30,4 \%), E 148 Q$ heterozygous in one $(4,3 \%)$, and compound heterozygous mutation in 3 . (13\%) patients. 16 patients used anakinra (100mg/day) for 6 mounths (median) and 7 used canacinumab (150mg/2 months) for 3 mounths (median). Four of 7 patiens were resistant to anakinra. After a median follow up 6 months overall clinical response [no attack (18 patients) or decreased frequency of attacks (5 patients)] was \%100. In an FMF patient with no mutation, his brother and mother had FMF with no mutations on MEFV gene. We achieved good clinical and laboratory responses in the patient by canacinumab.

Conclusions: Anti-IL-1 agents can be got involved in a new place safely and effectively in FMF patients along with colchicine. In addition, whole gene analysis should be done in refractory FMF patients with no mutations in order to could investigate new mutations, epigenetic mechanisms or other unexplained reasons. References:

[1] Ben-Chetrit E, Touitou I. Familial Mediterranean Fever in the world. Arthritis Rheum 2009; 61:1447-1453.

[2] Özdoğan H, Ugurlu S. The emerging treatments in Familial Mediterranean fever. In: Gattorno M, editor. Familial Mediterranean Fever, 1st edition, Switzerland: Springer; 2015:137-157

Disclosure of Interest: None declared
DOI: 10.1136/annrheumdis-2017-eular.6487

\section{AB0988 BEHÇET'S DISEASE IN A DEFINED AREA OF NORTHWESTERN SPAIN}

M. Estévez, A. Argibay, R. Lorenzo, M. Freire, J. Fernandez-Martín, B. Gimena, C. Vázquez-Triñanes, A. Rivera. Systemic Autoimmune diseases and Thrombosis Unit, University Hospital Complex of Vigo, Vigo, Spain

Background: Behçet's disease (BD) is a multisystemic inflammatory chronic disease. There is a wide variation in the clinical features of BD among geographical groups.

Objectives: To determine the demographic and clinical characteristics of BD in a defined area of northwestern Spain (Vigo).

Methods: Patients with BD (International Criteria BD) and seen in the University Hospital of Vigo in Spain, from 1994 to 2016, were retrospectively enrolled. Demographic, clinical, treatment and evolution data were recorded and analyzed using SPSS 22.0.

Results: Our patients were 26 male and 25 female. The mean age at the onset of the disease was $33 \pm 11.95$ years (11-62). Oral and genital ulcers were seen in $100 \%$ and $84.3 \%$ respectively and skin lesions in $88.2 \%$. Ocular involvement occurred in $35.3 \%$, neurological disease in $39.2 \%$ and gastrointestinal involvement in $29.4 \%$ (the area worst affected was colon and small bowel). Vascular disease was present in $33.3 \%$. See table 1. Pathergy test was performed in 18 patients $(35.29 \%)$ and $10(55.5 \%)$ were positives. HLA B51 was studied in only 13 patients (25.5\%) and $8(61.5 \%)$ were positives. $62.7 \%$ of patients had no cardiovascular risk factors (CVRF), $27.4 \%$ were smokers, $7.8 \%$ were hypertensive and $3.9 \%$ were hyperlipidemic and diabetic respectively. CVRF were not related to thrombotic events $(p>0.05)$. In regard to gender influence, only pseudofolliculitis was significantly more frequent in men $(p<0.001)$. There was a trend for increased prevalence of ocular disease and elevated erythrocyte sedimentation rate/serum C-reactive protein in men, and anemia in women, which, however, did not reach statistical significance. Treatment consisted of corticosteroids (92.2\%), colchicine $(68.6 . \%)$ and another immunosuppressive agent (35.3\%). During the disease course $78.4 \%$ of the patients had an outbreak, $45.1 \%$ initiated or changed to immunosuppressive agent and $19.6 \%$ used biological drugs. Most of our patients (92.1\%) were admitted to hospital and these constitute an evident bias. Two patients died during the followup period, but only one in relation of $\mathrm{BD}$ (upper gastrointestinal bleeding and seizures). Conclusions: Our series has some particular aspects especially the high frequency of gastrointestinal lesions and neurologic involvement. CVRF do not seem to play a role in the development of thrombotic events. Our results confirm the ethnic and geographic variation of BD expression.

Disclosure of Interest: None declared

DOI: 10.1136/annrheumdis-2017-eular.3983

\section{AB0989 RHEUMATOLOGIC COMPLICATIONS OF THALASSEMIA: SHOULD RHEUMATOLOGISTS JOIN THE MANAGEMENT TEAM?}

M.H.A. Noureldine ${ }^{1}$, A.T. Taher $^{2}$, A.A. Haydar ${ }^{3}$, A. Berjawi $^{2}$,

M.A. Khamashta ${ }^{4,5}$, I. Uthman ${ }^{2}$. ${ }^{1}$ Department of Neurosurgery, Lebanese American University; ${ }^{2}$ Department of Internal Medicine, American University of Beirut; ${ }^{3}$ Gilbert and Rose-Marie Chagoury School of Medicine, Lebanese American University, Beirut, Lebanon; ${ }^{4}$ Lupus Research Unit, St Thomas Hospital, London, United Kingdom; ${ }^{5}$ Department of Rheumatology, Dubai Hospital, Dubai, United Arab Emirates

Background: Beta-thalassemia major is accompanied by progressive multiple organ systems involvement due to the disease pathophysiology as well as iron overload from blood transfusions on a regular basis. Rheumatologists are not frequently involved in the multidisciplinary management of the disease, in which rheumatologic complications are relatively common.

Abstract AB0988 - Table 1. Clinical manifestation of our BD patients

\begin{tabular}{|c|c|c|c|c|}
\hline $\begin{array}{l}\text { Skin lesions } \\
41 / 55(88.2 \%)\end{array}$ & $\begin{array}{l}\text { Ocular disease } \\
18 / 51(35.3 \%)\end{array}$ & $\begin{array}{c}\text { Neurologic disease } \\
20 / 51(39.2 \%)\end{array}$ & $\begin{array}{l}\text { Vascular disease } \\
17 / 51(33.3 \%)\end{array}$ & $\begin{array}{c}\text { Gastrointestinal involvement } \\
15 / 51(29.4 \%)\end{array}$ \\
\hline $\begin{array}{l}\text { Pseudofolliculitis } 58.8 \% \\
\text { Erythema nodosum } 39.2 \% \\
\text { Leukocytoclastic vasculitis } 5.9 \%\end{array}$ & $\begin{array}{c}\text { Uveitis } 23.5 \% \\
\text { Retinal vasculitis 5.9\% } \\
\text { Episcleritis 3.9\% } \\
\text { Vascular occlusion 2\% }\end{array}$ & $\begin{array}{c}\text { Aseptic meningitis } 11.7 \% \\
\text { Seizures } 7.8 \% \\
\text { Cerebral venous thrombosis 5.9\% } \\
\text { White matter lesions } 5.9 \% \\
\text { Stroke } 3.9 \% \\
\text { Paresthesias } 3.9 \% \\
\text { Others } 5.9 \%\end{array}$ & $\begin{array}{l}\text { Venous thrombosis } 21.6 \% \\
\text { Arterial thrombosis } 7.8 \% \\
\text { Mixed thrombosis } 2 \% \\
\text { Aneurysm } 2 \%\end{array}$ & $\begin{array}{c}\text { Pain } 11.7 \% \\
\text { Bleeding } 9.8 \% \\
\text { Diarrhea } 5.9 \% \\
\text { Fever } 2 \%\end{array}$ \\
\hline
\end{tabular}


Objectives: To highlight the rheumatologic complications of beta-thalassemia, which include musculoskeletal manifestations such as arthritis and arthropathies, joint effusions, osteoporosis, bone fractures, and arthralgias as well as connective tissue diseases such as pseuoxanthoma elasticum (PXE).

Methods: We searched the literature through GoogleScholar and PubMed for all publications reporting on rheumatologic manifestations in beta-thalassemia. The following keywords were used: thalassemia, rheumatoid arthritis, osteoarthritis, iron-overload, septic arthritis, deferiprone-related arthropathy, crystal arthritis, effusions, osteoporosis, fractures, bone marrow hyperplasia, scoliosis, aseptic necrosis, arthralgia, myalgia, and pseudoxanthoma elasticum. All reports published between 1970 and 2016 were included.

Results: Arthralgia and low back pain are among the most common musculoskeletal manifestations of thalassemia. Many studies are reporting an increased rate of RA in hemoglobinopathies such as thalassemia, the association of which may be attributed to genetic factors. Arthritis may develop secondary to iron deposition in the synovial tissue or due to iron chelators such as deferiprone, which may provoke a self-limited arthritis due to synovial destruction sustained by free radicals production during iron interchange. Several studies reported increased incidence $(16 \%>30 \%)$ of arthropathy in beta-thalassemia patients on deferiprone therapy. Multiple etiologies contribute to osteoarthritis in thalassemia patients such as bone marrow expansion, iron deposition within the joint, and hypoparathyroidism. Only few cases of Salmonella enteriditis septic arthritis were described in thalassemia patients. The associations between osteoporosis and hypogonadism, diabetes, and vitamin $\mathrm{D}$ and calcium deficiency were found significant. Skin lesions of PXE were reported in up to $16 \%$ in beta-thalassemics. Conclusions: The pathophysiology of thalassemia and subsequent blood transfusions affect almost every organ system. Rheumatologic manifestations ranging from musculoskeletal complications to connective tissue diseases are common among thalassemia patients. Rheumatologists are highly encouraged to be involved in the multidisciplinary approach for the management of beta-thalassemia. Disclosure of Interest: None declared

DOI: 10.1136/annrheumdis-2017-eular.3332

\section{AB0990 PERI-ARTERITIS AS A NOVEL PARANEOPLASTIC PRESENTATION OF MYELODYSPLASTIC SYNDROME: A CASE SERIES AND REVIEW OF THE LITERATURE}

N. Droz, C. Gota. Rheumatology, Cleveland Clinic Foundation, Cleveland, United States

Background: Myelodysplastic syndromes (MDS) are characterized by ineffective and dysplastic hematopoiesis resulting in peripheral blood cytopenias with varying risk for progression to acute myelogenous leukemia (AML) ${ }^{1}$.

Autoimmune manifestations have been well described in association with MDS $^{2}$. Peri-arteritis has rarely been reported.

Objectives: Here, we present a novel association of MDS with peri-arteritis.

Methods: Three patients within our institution and one in the literature were identified. Patients were diagnosed with MDS according to 2008 World Health Organization classification with concomitant occurrence of peri-arteritis on imaging ${ }^{3}$. Results: See Table 1.

Conclusions: Autoimmune manifestations associated with MDS occur in 7$25 \%$ of patients. The most commonly reported conditions include vasculitis, inflammatory arthritis and connective tissue disease. There is a paucity of literature describing peri-arteritis associated with $\mathrm{MDS}^{2}$. Review of the literature revealed only one other case of peri-arteritis associated with MDS outside of those identified at our facility ${ }^{4}$

With this case series, we report peri-arteritis as a novel presentation of MDS. Peri-vascular inflammation may mimic idiopathic retroperitoneal fibrosis, however, persistent cytopenias, lack of response to immunosuppressive therapy and persistence of elevated inflammatory markers should prompt the physician to evaluate for an underlying diagnosis of MDS.
References:

[1] Ades L, Itzykson R, Fenaux P. Myelodysplastic Syndromes. Lancet. 2014;383(9936):2239-52.

[2] Mekinian A, Grignano E, Braun T et al. Systemic inflammatory and autoimmune manifestations associated with MDS. Rheumatology.2016;55(2):291-300.

[3] Swerdlow S, Campo E, Harris N et al. WHO Classification of Tumours of Haematopoietic and Lymphoid Tissues. Lyon, France: IARC Press; 2008.

[4] Inoue M, Kano T, Ozaki T et al. Rheumatic manifestations and an epipharyngeal mass accompanied by MDS. Mod Rheumatol. 2015;25(4):653-6.

Disclosure of Interest: None declared

DOI: 10.1136/annrheumdis-2017-eular.1557

\section{AB0991 PREVALENCE OF FIBROMYALGIA AND DEPRESSION IN PATIENTS WITH AUTOIMMUNE /INFLAMMATORY SYNDROME INDUCED BY ADJUVANTS COMPARED TO PATIENTS WITH SYSTEMIC SCLEROSIS}

O. Vera-Lastra, P. Blas Hernadez, A. Sánchez-Rodríguez, L.J. Jara. Internal Medicine, Hospital Especialidades CMN la Raza. Instituto Mexicano Seguro Social, Mexico City, Mexico

Background: Autoimmune/inflammatory syndrome induced by adjuvants (ASIA) has been associated with previous exposure to various agents such as mineral oil, silicone and vaccines, which act as adjuvants eliciting chronic stimulation of the immune system and manifestation of autoimmune diseases. There is little information about fibromyalgia (FM), depression and the deterioration of the quality of life in ASIA patients.

Objectives: To determine the prevalence of FM, depression and both in ASIA patients associated to mineral oil versus systemic sclerosis (SSc) patients.

Methods: A comparative cross-sectional study was performed in patients with ASIA according to Shoenfeld's criteria associated to injection of mineral oil with cosmetic purposes. The prevalence of fibromyalgia according to criteria of ACR, depression by Beck questionnaire and quality of life with FS-36 in patients with ASIA versus patients with systemic sclerosis matched by age were evaluated.

Results: There were 100 women, 50 ASIA patients (mean age $49 \pm 9.7$ years) compared to $50 \mathrm{SSc}$ patients (mean age $49 \pm 10$ years). Of patients with ASIA, 40 patients had non-specific rheumatic disease and 10 met ACR criteria for SSc in 4 patients, SLE 3 and overlap syndrome 1 (SLE plus SSc) and rheumatoid arthritis 2. In ASIA vs. SSc we found depression in $72 \%$ vs $46 \%$ respectively, $p<0.005$, fibromyalgia in 66 vs $48 \%, p<0.008$ and fibromyalgia plus depression in $56 \%$ vs. $28, p<0.005$. Patients with ASIA had a worse quality of life than SSc by SF36 and the most affected parameter was the emotional one.

Conclusions: ASIA patients associated to injection of mineral oild had higher prevalence of depression, fibromyalgia and greater deterioration of quality of life compared to SSc patients. There is a possible link between ASIA, depression and FM.

\section{References:}

[1] Agmon-Levin $\mathrm{N}$ et al. Chronic fatigue syndrome and fibromyalgia following immunization with hepatitis Bvaccine:another angle of autpimmune (auto-inflammatory)syndrome induced by adjuvants (ASIA). Immunol Res 2014;60:376-82.

[2] Vera Lastra o, et al. Autoimmune /Inflammatory syndrome induced by adjuvants (Shoenfeld's syndrome):clinical and immunological spectrum. Expert Rev Clibn Immunol 2013;9:361-73.

[3] Jara LJ; et al. Severe manifestation of autoimmune syndrome induced by adjuvants (shoenfeld's syndrome. Immunol Res 2016 Jul 13.

Disclosure of Interest: None declared

DOI: 10.1136/annrheumdis-2017-eular.6263

Abstract AB0990 - Table 1

\begin{tabular}{|c|c|c|c|c|}
\hline Patient & 1 & 2 & 3 & $4^{4}$ \\
\hline Age & 67 & 37 & 67 & 70 \\
\hline Sex & Female & Female & Female & Male \\
\hline MDS type & CMML-1 & $\begin{array}{l}\text { MDS with multi-lineage dysplasia; } \\
\text { progression to AML }\end{array}$ & MDS Unclassifiable & MDS with multi-lineage dysplasia \\
\hline Presenting Symptoms & $\begin{array}{l}\text { Hydronephrosis, abdominal pain, } \\
\text { weight loss }\end{array}$ & Serositis, dyspnea, fevers, rash & $\begin{array}{l}\text { Rapidly evolving peri-arteritis, } \\
\text { adominal pain }\end{array}$ & $\begin{array}{l}\text { Organizing pneumonia, fever, } \\
\text { arthralgias }\end{array}$ \\
\hline Bone Marrow Biopsy & Hypercellular, features of CMML-1 & $\begin{array}{l}\text { Normocellular, multilineage dysplasia, } \\
4 \% \text { blasts, } 20 q \text { deletion }\end{array}$ & $\begin{array}{l}\text { Hypercellular, granulocytic } \\
\text { hyperplasia, } 2 \% \text { blasts }\end{array}$ & Normocellular, multilineage dysplasia \\
\hline ANCA and ANA & Negative & Negative & Negative & Negative \\
\hline ESR $(0-15 \mathrm{~mm} / \mathrm{hr})$ & 21 & 76 & 57 & \\
\hline $\operatorname{CRP}(<0.9 \mathrm{mg} / \mathrm{dL})$ & 5.4 & 31.2 & 4.9 & 9 \\
\hline Radiographic extent of peri-arteritis & $\begin{array}{l}\text { Infra-renal abdominal aorta and } \\
\text { common iliac arteries }\end{array}$ & Thoracic aorta and branch vessels & $\begin{array}{l}\text { Carotid arteries, thoracic and } \\
\text { abdominal aorta, femoral vessels }\end{array}$ & Internal carotid artery \\
\hline Treatment & Corticosteroids & $\begin{array}{l}\text { Corticosteroids, anakinra, } \\
\text { methotrexate, IVIG }\end{array}$ & Corticosteroids & Corticosteroids \\
\hline Clinical Course & $\begin{array}{l}\text { Ureteral stenting and nephrostomy } \\
\text { tube placement improved symptoms. } \\
\text { Inflammatory markers remained } \\
\text { elevated despite treatment. }\end{array}$ & $\begin{array}{l}\text { Multiple treatment modalities failed to } \\
\text { improve symptoms or inflammatory } \\
\text { markers. MDS transformed to AML } \\
\text { requiring stem cell transplant. Her } \\
\text { disease was then quiescent. }\end{array}$ & $\begin{array}{l}\text { Despite treatment, disease was } \\
\text { complicated by aortic dissection which } \\
\text { was managed non-operatively. } \\
\text { Azacitidine was initiated but she died } \\
\text { of infectious complications. }\end{array}$ & $\begin{array}{l}\text { Epipharyngeal mass improved with } \\
\text { corticosteroids. Disease course was } \\
\text { complicated by infection. }\end{array}$ \\
\hline
\end{tabular}

